\title{
Ratchet Effect in Import Prices - Inflation Rate Nexus
}

Received: 23.04.2021

Available online: 29.09.2021

\section{Mutiu A. Oyinlola*, Tirimisiyu F. Oloko*, Samuel Orekoya***}

\begin{abstract}
This study examined the existence of the ratchet effect in the import price-inflation rate nexus for advanced (high-income) and emerging (middle-income) countries. The study used monthly data from 1980M01 to 2019M07 and compared the potential of the dummy variable-based asymmetric model with that of the Nonlinear Autoregressive Distributed Lag (NARDL) model in modelling the ratchet effect. The result showed that the ratchet effect exists in the import priceinflation rate nexus for high-income and middle-income countries. This suggests that the issue of imported inflation and ratchet effect is country-specific. The significance of the ratchet effect in these countries implies that maintaining a (symmetric) rulebased counter-cyclical monetary policy when dealing with import price shocks would be inefficient, and can make monetary policy harm the economy in the medium to the long term. It is, therefore, recommended that each country should examine the existence or otherwise of ratchet in her import price-
\end{abstract}

inflation rate nexus to determine whether it should adopt a symmetric or an asymmetric rule-based counter-cyclical monetary policy against import price shocks to avoid harming the economy through the implementation of an inefficient monetary policy.

Keywords: Imported inflation, Ratchet effect, Middle income countries, Asymmetric Modelling

JEL: C22, E31, F41.

\section{Introduction}

The monetary policy goal of maintaining low and stable inflation requires a good understanding of the dynamics of inflation in every economy (Oloko et al., 2021). Due to the rising degree of trade and economic integration, recent studies have started to acknowledge the significance of foreign price transmission (pass-through) on domestic inflation, often denoted as "imported inflation" (McCarthy, 2007; Lagoa, 2014; Salisu et al., 2018). However, little attention has been paid to the potential existence of ratchet effect in the relationship between the prices of imported goods and domestic prices, which may cause the wrong implementation of monetary policy. The term "ratchet effect" was commonly used in the principal-agent or employer-worker

Department of Economics, University of Ibadan, Ibadan, Nigeria.

** Department of Economics, University of Ibadan, Ibadan, Nigeria; Centre for Econometric and Allied Research (CEAR), University of Ibadan, Ibadan, Nigeria.

*** Department of Economics, University of Ibadan, Ibadan, Nigeria. 


\section{Articles}

relationship, to refer to a situation where workers subject to performance pay choose to restrict their output because they rationally anticipate that firms will respond to higher output levels by raising output requirements or by cutting pay (see also, Charness et al., 2011; Cardella and Depew, 2018; Wei, 2020). In this case, the output of the worker is sticky upward. The ratchet effect in the import prices-inflation nexus, as postulated by the Keynes' General Theory, was based on the hypothesis of downward rigidity in wages and prices, which suggests asymmetry in the effect of import prices on domestic prices.

Commonly known as the Mundell-Laffer hypothesis, the ratchet effect implies an upward bias in the response of domestic prices to changes in import prices (Goldstein, 1977). Relying on the assumption of downward rigidity in wages and prices, ratchet effect in import prices-inflation rate nexus simply explains that lower import prices do not cause a reduction in domestic prices as much as an increase in import prices will cause an increase in domestic prices. In other words, higher (lower) import prices of equal magnitude do not increase (reduce) domestic prices equivalently. The existence of a significant ratchet effect in import prices-inflation rate nexus implies that strict commitment to monetary policy rule may cause the monetary authority to overreact to negative import price shocks, which may further harm the economy (Bernanke et al., 1997; Kormilitsina, 2011; Oloko et al., 2021).

Based on its significance, particularly, in determining appropriate monetary policy to deal with imported inflation, there has been growing literature on the analysis of the ratchet effect of import prices on inflation rate (see, for example, Rassekh and Wilbratte, 1990; Shirvani and Wilbratte, 1999; Rassekh and
Ranjbar, 2014; Alsamara et al., 2018, 2020). However, these studies either concentrate on the advanced economies (see Rassekh and Wilbratte, 1990; Shirvani and Wilbratte, 1999; Rassekh and Ranjbar, 2014) or emerging economies (Alsamara et al., 2018, 2020; Hottman and Monarch, 2020). To the best of our knowledge, no study has compared the nature of the ratchet effect in the import priceinflation nexus of the developed countries with the emerging countries. In other words, the question, does the ratchet effect hold in the relationship between import prices and inflation rate for developed countries as well as emerging countries? remained answered in the literature. Meanwhile, Hottman and Monarch (2020), in their analysis of import price inflation for different income deciles of U.S. consumers over the years 1998 through 2014 found that lower-income households experienced the most import price inflation, while higher-income households experienced the least over the period. This suggests that the nature of the ratchet effect in the import price-inflation nexus may be different in the developed countries and emerging countries.

To fill this gap, therefore, this study investigates the ratchet effect in the import prices-inflation rate nexus for both developed (high income) and emerging (upper middle income) economies. In conducting this analysis, we employed both the dummy variable-based asymmetric autoregressive distributed lag (ARDL) model and the recently developed non-linear autoregressive distributed lag (ARDL) model (Alsamara et al., 2020), both based on the Bound testing cointegration approach. This allows us to identify the estimation technique with better asymmetric properties for determining the ratchet effect in the import prices-inflation relationship. Our results show that imported 


\section{Articles}

inflation and ratchet effect exist in high-income as well as middle-income countries, suggesting that the issue of imported inflation and ratchet effect is country-specific. Further results reveal that the nonlinear ARDL is more efficient in determining the ratchet effect in import priceinflation nexus than the dummy variablebased asymmetric autoregressive distributed lag (ARDL).

The following sections are organised as follows. Section 1 deals with the review of the literature. Section 2 presents the background and data issues. Section 3 discusses the methodology adopted and its framework. Section 4 presents the results and empirical analysis, while section 5 concludes the paper.

\section{Literature Review}

With the growing level of global trade and financial connections, the potential effect of foreign prices on the domestic inflation rate can no more be ignored (Tootell, 1998). Extant literature on import prices-inflation nexus can be categorized into two. The first category consists of those studies that do not investigate the significance of the ratchet effect in the relationship, while the second category consists of those that investigated the significance of the ratchet effect in the relationship. The first category includes Corrigan (2005), McCarthy (2007), Unsal (2013), Wu et al. (2017), and Abbas and Lan (2020), while the second category consists of Rassekh and Wilbratte (1990), Shirvani and Wilbratte (1999), Rassekh and Ranjbar (2014) and Alsamara et al. (2018; 2020).

In reference to the first category, Corrigan (2005) analysed the relationship between import prices and inflation in the United States. Adopting the "triangle model," the study supports the view that import prices have played a significant role in explaining the United States inflation patterns. Also, McCarthy (2007) investigated the passthrough of exchange rates and import prices to domestic inflation in nine selected industrialised economies: The United States, Japan, Germany, France, the United Kingdom, Belgium, the Netherlands, Sweden, and Switzerland. Relying on a model of pricing along a distribution chain and using a VAR model that incorporates a distribution chain, the study finds that the pass-through to aggregate consumer prices, which is the principal concern for monetary policy, appears to be modest in most of these countries.

Similarly, Osorio and Unsal (2013) investigated the drivers of inflation in thirtythree Asian countries and how these have changed over time between the period 1986:Q1-2010:Q1. Employing Structural VAR (SVAR) and Global VAR (GVAR) models, the study revealed that economies in the region are exposed to notable inflation spillovers from China, both directly from higher prices of imported goods and indirectly through higher prices of commodities. Wu et al. (2017) research the price transmission effect of China's imported commodities. They find evidence of the price transmission effect in China's imported commodities. Abbas and Lan (2020) examined the effect of energy and commodity prices on the inflation process of some developed and emerging countries. They find that the dynamics of inflation and commodity prices change with the inflation environment.

As regards the second category, Rassekh and Wilbratte (1990) examined the effect of import price changes on domestic inflation to confirm the existence of the ratchet effect. The study focused on five major OECD countries: the United States, the United Kingdom, Canada, Japan, and West 


\section{Articles}

Germany, with data covering the third quarter of 1972 through the second quarter of 1987. The results suggest that prices respond symmetrically to variation in the rate of import price change. This implies that there is no ratchet effect. Also, Shirvani and Wilbratte (1999) examined the possibility that, in the short run, the domestic price level responds asymmetrically to import price changes, using the multivariate co-integration approach. For a sample of five major industrial countries, the study found that, in most cases, the general price level rises more readily than it falls.

Rassekh and Ranjbar (2014) investigated the existence of ratchet effect in OECD countries using annual data of 24 OECD countries, for the period 1985-2009. The study found that the response is asymmetrical: domestic prices rise when import prices rise but they do not fall when import prices fall, which is a confirmation of the ratchet effect. Also, Alsamara et al. $(2018,2020)$ examined asymmetric responses of consumer prices to import costs in Gulf Cooperation Council (GCC) countries using a non-linear approach and quarterly data from 1990 to 2014 . The studies confirm the ratchet effect for these countries, as inflation was found to respond more to positive shocks than to negative shocks.

The present study contributes to the second category by investigating the ratchet effect in import prices inflation rate nexus. A critical review of the literature reveals that earlier studies in this category investigated either advanced economies (see Rassekh and Wilbratte, 1990; Shirvani and Wilbratte, 1999; Rassekh and Ranjbar, 2014) or emerging economies (see Alsamara et al., 2018; 2020). This does not allow for comparison of the relationship under different economic conditions. Meanwhile, the finding by Hottman and Monarch (2020) that lowerincome households experienced the most import price inflation, while higher-income households experienced the least over the period suggests that the nature of the ratchet effect in the import price-inflation nexus may be different in high income and middleincome countries. Our innovation is similar to the one made by Abbas and Lan (2020) in the first category of the literature. Hence, this study will be an extension of the literature in the second category, where the significance of the ratchet effect is examined.

\section{Background and Data issues}

A recent study by Salisu et al. (2019) noted that high-income countries tend to have lower inflation rates than their middle-income counterpart. This fact was also verified in this study. As evident from Figure 1, the inflation rate of the high-income countries group lies consistently below the inflation rate for low (upper middle) income countries between 1980 and 2018. More noticeable is the fact that the inflation rate of high-income countries has been falling consistently in this period, while middle-income countries experienced a sharp inflation shock in the 1990s. This shock may not be unconnected with the spiral inflation rate of about 843 percent experienced in Brazil in the 1990s. On average, the inflation rate of high-income countries fell from 6.1 percent in the $1980 \mathrm{~s}$, to 3.22 percent in the 1990s, 2.48 percent in the 2000s, and 1.62 percent between 2010 and 2018. On the other hand, the inflation rate of middle-income countries increased from 10.41 percent in the 1980 s to 12.08 percent in the 1990 s. It then fell rapidly from 12.08 percent to 5.67 percent in the 2000s and 3.18 percent between 2010 and 2018 (Table 1). 


\section{Articles}

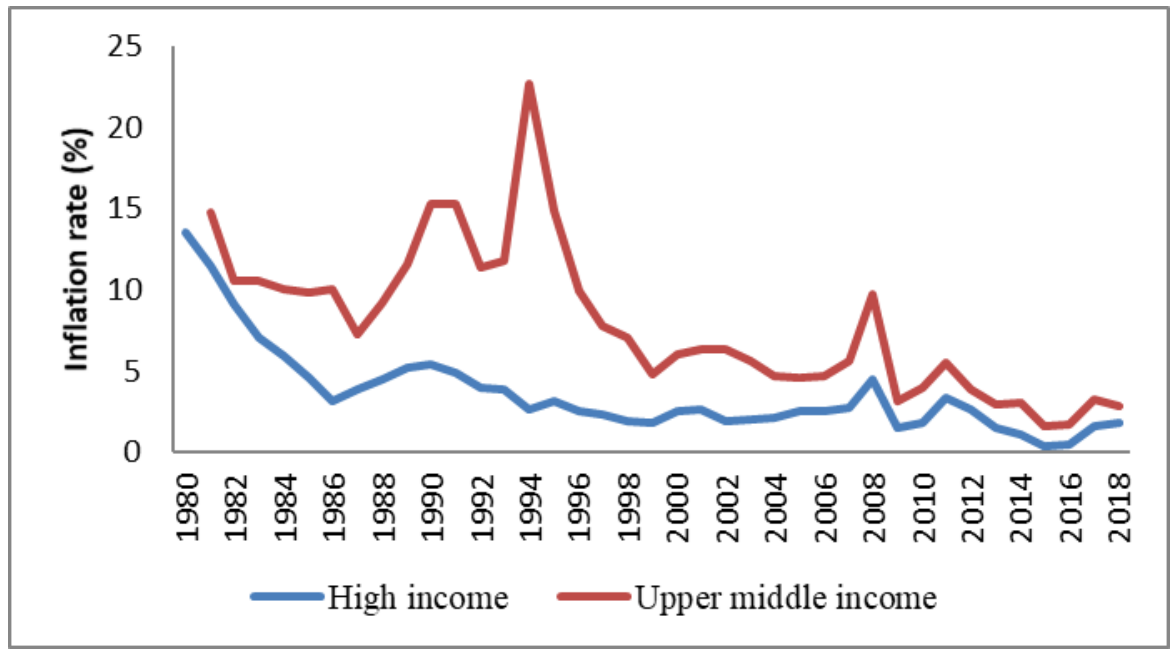

Figure 1: Inflation rate of high income and low (upper middle) income countries Source: Inflation, consumer prices (annual \%), World Development Indicators (WDI)

Table 1: Trends in Inflation rate

\begin{tabular}{|l|l|l|l|l|}
\hline \multicolumn{1}{|c|}{ Countries } & \multicolumn{1}{c|}{$\mathbf{1 9 8 0 - 1 9 8 9}$} & \multicolumn{1}{c|}{$\mathbf{1 9 9 0 - 1 9 9 9}$} & \multicolumn{1}{c|}{$\mathbf{2 0 0 0 - 2 0 0 9}$} & \multicolumn{1}{c|}{$\mathbf{2 0 1 0 - 2 0 1 8}$} \\
\hline High income & $\mathbf{6 . 1 0}$ & $\mathbf{3 . 2 2}$ & $\mathbf{2 . 4 8}$ & $\mathbf{1 . 6 2}$ \\
\hline Czech Republic & - & 10.14 & 2.78 & 1.56 \\
\hline Denmark & 6.91 & 2.11 & 2.11 & 1.28 \\
\hline Estonia & - & 30.20 & 4.31 & 2.34 \\
\hline Finland & 7.18 & 2.18 & 1.70 & 1.32 \\
\hline Germany & 2.87 & 2.44 & 2.12 & 1.51 \\
\hline Greece & 19.47 & 11.11 & 3.16 & 0.72 \\
\hline Korea Rep. & 8.40 & 5.74 & 3.12 & 1.87 \\
\hline Lithuania & - & 80.21 & 3.02 & 1.79 \\
\hline Slovenia & 217.13 & 97.53 & 4.90 & 1.20 \\
\hline Sweden & 7.94 & 3.29 & 1.47 & 1.05 \\
\hline UK & 7.16 & 3.62 & 1.94 & 2.10 \\
\hline US & 5.55 & 3.00 & 2.57 & 1.77 \\
\hline Upper middle income & $\mathbf{1 0 . 4 1}$ & $\mathbf{1 2 . 0 8}$ & $\mathbf{5 . 6 7}$ & $\mathbf{3 . 1 8}$ \\
\hline Brazil & 354.53 & 843.25 & 6.89 & 6.05 \\
\hline Paraguay & 20.21 & 16.39 & 8.26 & 4.34 \\
\hline
\end{tabular}

Source: World Development Indicators (WDI)

Meanwhile, as evident from Figure 1, the 1 and middle income) in the world has been inflation rate of many countries (high income declining. Except for Brazil, which experienced 


\section{Articles}

a higher inflation rate in the 1990s, all other 13 countries considered experienced falling inflation rates. More so, while the inflation rates of Brazil and Paraguay averaged 6.05 percent and 4.34 percent, respectively, between 2010 and 2018, the highest inflation rate of any high-income country is 2.34 percent, reported by Estonia. The problem of high inflation rate in Slovenia and Greece in the 1980s appears to have been sufficiently tamed, as Greece reported the lowest inflation rate of 0.72 percent amongst the high-income countries, while the inflation rate of Slovenia reduced from a very high rate of 217.13 percent in the 1980s to 1.20 between 2010 and 2018 . Another historically high inflation rate country among the high-income countries is Lithuania. This country's inflation has also been tamed to remain at 1.79 percent between 2010 and 2018; falling from the high rate of 80.21 percent in the 1990s.

The raw monthly data for consumer price index (CPI), import price index (IMP), and industrial production index was obtained from the International Financial Statistics (IFS), while data for West Texas Intermediate (WTI) oil price was obtained from Energy Information Administration (EIA). The CPI, IMP, and WTI data are logged in the model, while the output gap was computed using the Hodrick-Filter approach on the industrial production index (IPI); which is the proxy for economic productivity. In terms of the preliminary analysis, the statistical features of the variables examined include the descriptive statistics consisting of mean, standard deviation, and Jarque-Bera statistics for testing the normality of the series. Others include the Ljung-Box $Q$ statistic test for serial correlation and the unit root test using the Augmented Dickey-Fuller (ADF) and PhillipPerron (PP) approaches.
Ratchet Effect in Import Prices - Inflation Rate Nexus

Tables $2 \mathrm{a}$ and $2 \mathrm{~b}$ present the statistical features for domestic price level and the level of import prices of the selected countries, respectively. As may be noted from the tables, the data coverage and eventually the number of observations for each country vary, which is due to data availability. Thus, the number of observations ranges from 475 as in the case of the Republic of Korea and the United States of America (1980M01-2019M07) to 108 as in the case of Paraguay and Lithuania (2010M01-2018M12). It is however notable that the minimum number of observations, 108, considered in this study is sufficient enough $(>30)$ and fulfills the asymptotic properties for the proposed time series modelling techniques - the Autoregressive Distributed Lag (ARDL) Bound Testing co-integration approach by Pesaran and Shin(1999) and Pesaran et al.(2001), and nonlinear version by Shin et al. (2014).

From Table 2a which presents the summary statistics for price levels (log of consumer price indexes) in high and middle-income countries considered, it was noted that on average (using the mean values), the highest price level was recorded by Paraguay and Brazil; thus, confirming that middle-income countries have higher inflation rate potential than the higher income countries (see Salisu et al., 2019). Among the upper-income countries, Estonia is the highest inflation trending country, followed by Lithuania, the Czech Republic, and Slovenia. The lowest inflation trending country is the United States of America (USA). It is followed by the United Kingdom (UK) and Sweden in that order. More importantly, in Table 2b, Paraguay which recorded the highest domestic prices level also recorded the highest import price level. In addition, the high-income countries with relatively higher domestic prices such as 


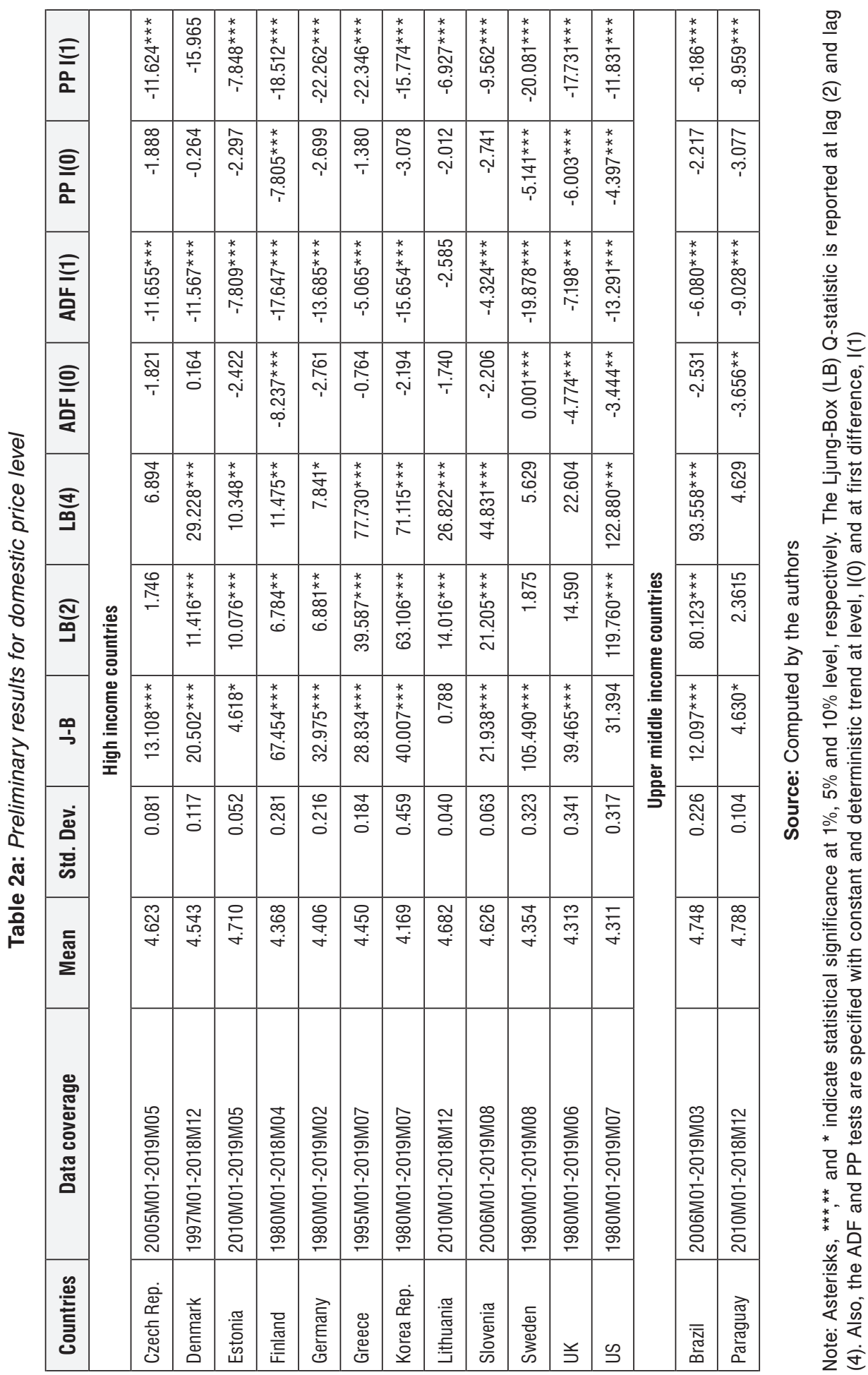




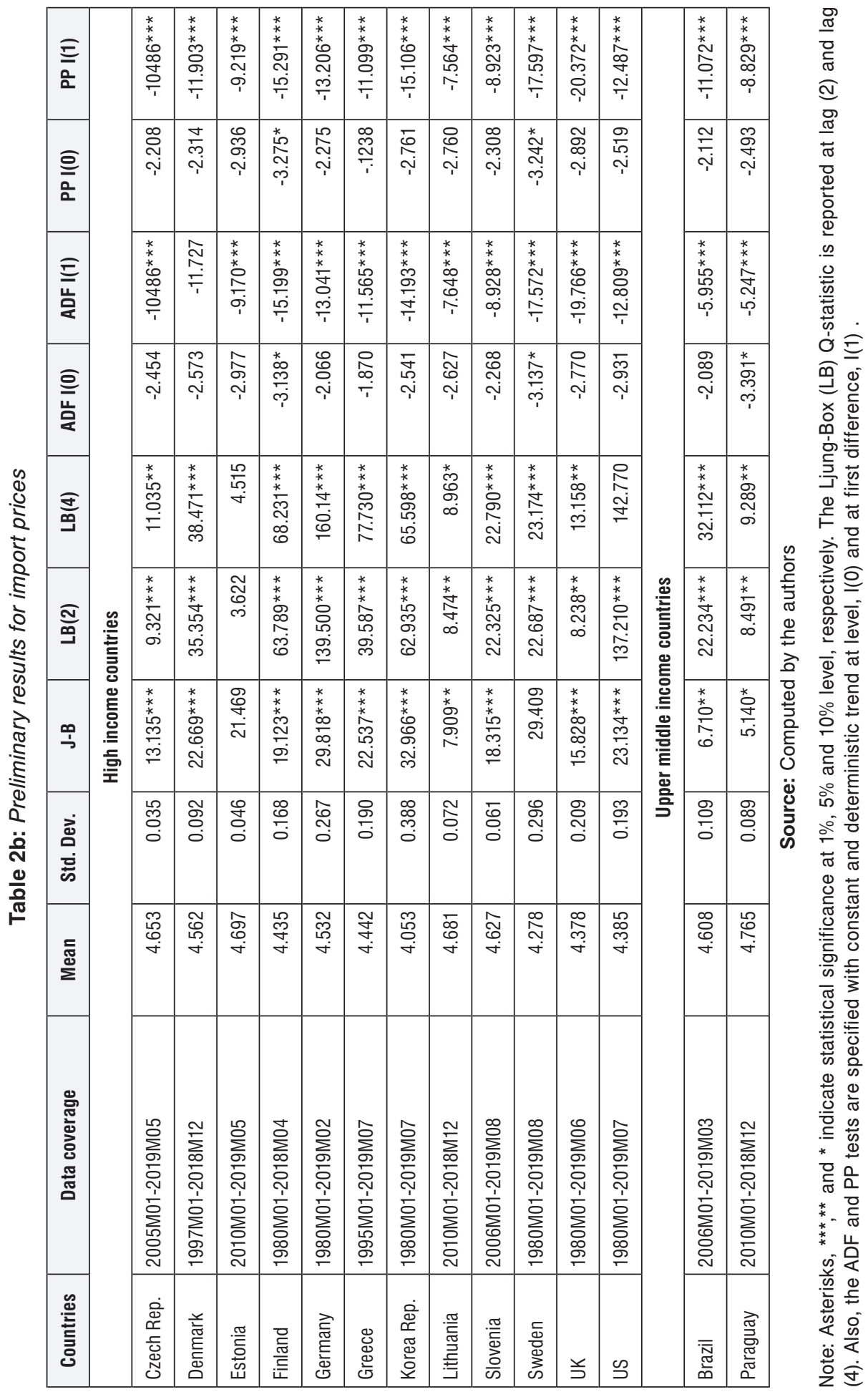




\section{Articles}

Estonia, Lithuania, the Czech Republic, and Slovenia are also noticed to have relatively higher import prices in the group. This suggests that the possibility of high import prices translating to high domestic prices cannot be dispelled.

Meanwhile, the Jarque-Bera statistics show that the domestic price series for all the countries, except the USA and Lithuania, are not normally distributed, as the normality hypothesis is significantly rejected for the respective countries. In addition, the null hypothesis of no serial correlation is rejected for all countries except the Czech Republic, Sweden, Paraguay, and the UK. The domestic price series for Finland, the UK and, the USA are stationary at level, I(0), as confirmed by both ADF and PP unit root results. This suggests short-term price level adjustment and efficient working of price mechanisms in these countries. Conversely, the unit root hypothesis cannot be rejected for the import price series for Finland, the UK, and the USA at 5 percent level; suggesting that the import price - inflation rate model for these countries consists of a mixture of $\mathrm{I}(0)$ and $\mathrm{I}(1)$ series. Evidence of mixture of $\mathrm{I}(0)$ and $\mathrm{I}(1)$ series becomes conspicuously glaring considering the unit root results for output gap and crude oil price (in Table 2c).

Table 2c: Preliminary results for output gap (YG) and oil price (OP)

\begin{tabular}{|c|c|c|c|c|c|c|}
\hline \multirow{2}{*}{ Countries } & \multicolumn{3}{|c|}{ Output gap (YG) } & \multicolumn{3}{|c|}{ Oil Price (OP) } \\
\hline & Mean & ADF I(0) & ADF I(1) & Mean & ADF I $(0)$ & ADF I(1) \\
\hline \multicolumn{7}{|c|}{ High income countries } \\
\hline Czech Rep. & $-9.40 \mathrm{E}-13$ & -3.0111 & $-11.610 * * *$ & 4.2393 & -3.0829 & $-9.1279 * * *$ \\
\hline Denmark & $3.66 \mathrm{E}-13$ & $-10.410^{\star * \star}$ & $-12.345^{\star * *}$ & 3.8681 & -1.8732 & $-12.215^{\star \star \star}$ \\
\hline Estonia & $-1.30 \mathrm{E}-12$ & $-3.5676^{\star *}$ & $-11.592^{\star * *}$ & 4.2464 & -2.3585 & $-7.8107^{\star \star \star}$ \\
\hline Finland & $6.81 \mathrm{E}-13$ & $-10.918^{\star \star \star}$ & $-17.742^{\star \star \star}$ & 3.5365 & -2.9585 & $-15.831^{\star * *}$ \\
\hline Germany & $4.98 \mathrm{E}-13$ & $-5.9896^{\star \star *}$ & $-21.457^{* \star *}$ & 3.5492 & -2.9918 & -15.990 *** \\
\hline Greece & $8.81 \mathrm{E}-13$ & $-13.749 * * \star$ & $-10.266^{* \star *}$ & 3.8019 & -2.1676 & $-13.086^{\star * *}$ \\
\hline Korea Rep. & $1.30 \mathrm{E}-13$ & $-5.2638 * \star \star$ & $-18.929 * \star *$ & 3.5547 & -3.0135 & $-16.107^{\star * *}$ \\
\hline Lithuania & $-1.12 \mathrm{E}-12$ & $-8.2169 * * \star$ & $-10.563^{* * *}$ & 4.2553 & -2.4166 & $-7.4515^{\star * *}$ \\
\hline Slovenia & $1.48 \mathrm{E}-13$ & -3.0282 & $-12.722^{\star \star *}$ & 4.2507 & -3.0470 & $-8.7916^{\star \star \star}$ \\
\hline Sweden & $2.96 \mathrm{E}-13$ & $-6.1363^{* * *}$ & $-25.841^{* * *}$ & 3.5557 & -2.9937 & $-16.138 * * *$ \\
\hline UK & $-4.79 \mathrm{E}-15$ & $-17.792^{* * *}$ & $-17.553^{\star * *}$ & 3.5537 & -2.9918 & $-16.015^{\star * \star}$ \\
\hline US & $7.66 \mathrm{E}-13$ & $-5.5341^{* * *}$ & $-23.241^{* \star *}$ & 3.5548 & -3.0135 & $-16.107^{* * *}$ \\
\hline \multicolumn{7}{|c|}{ Upper middle income countries } \\
\hline Brazil & 2.97E-13 & $-7.8751^{\star * \star}$ & $-8.2818^{* * *}$ & 4.2566 & -3.0041 & $-8.5571^{* * *}$ \\
\hline Paraguay & $-8.79 \mathrm{E}-13$ & $-6.0927^{\star * *}$ & $-6.9442^{* * *}$ & 4.2553 & -2.4166 & $-7.4515^{\star \star \star}$ \\
\hline
\end{tabular}

Source: Computed by the authors

Note: Asterisks, ${ }^{* * * * *}$ and * indicate statistical significance at $1 \%, 5 \%$ and $10 \%$ level, respectively. The ADF test is specified with constant and deterministic trends at level, I(0) and at the first difference, I(1).

From Table 2c, it is evident that the output gap series is stationary for all the countries, except for the Czech Republic and Slovenia, while oil price is I(1) under different sub- 


\section{Articles}

samples for the respective countries. These further validate the suitability of ARDL and NARDL approaches proposed in this study (see also, Oyinlola and Oloko, 2018). As output gap is defined as the difference between actual and potential output, a negative output gap as in the case of the Czech Republic, Estonia, Lithuania, and the United Kingdom suggests that these countries operate below their potential. Ordinarily, this should suggest the existence of a relatively lower inflation rate in these countries. This appears true in the case of the United Kingdom, which is among the low inflation countries. Conversely, however, the Czech Republic, Estonia, and Lithuania are among the high inflation trending countries. Given that these countries recorded relatively higher import prices, it is not inconsistent to assume that the relatively high inflation in the Czech Republic, Estonia, and Lithuania are imported rather than domestically generated.

\section{Methodology}

The main objectives of this study are twofold. The first is to verify the existence of imported inflation, and the second is to examine the existence of the ratchet effect. To validate the existence of imported inflation, import prices are expected to positively and significantly influence the inflation rate; such that higher import prices cause higher domestic prices. To validate the ratchet effect hypothesis, the effects of rising and falling import prices on domestic prices are expected to be different (Rassekh and Ranjbar, 2014). Earlier studies on import prices and inflation rate relationship have adopted a dummy variable-based approach to examine the existence of ratchet effect in the import prices-inflation rate dynamics (see, for example, Rassekh and Wilbratte, 1990; 1999; Rassekh and Ranjbar, 2014). One of the key contributions of this study to the literature on import prices-inflation rate nexus is to compare the potential of this conventional approach to that of the recently developed NARDL model, in determining the significance of the ratchet effect in import price-inflation nexus.

\subsection{Dummy variable-based asymmetric approach}

The dummy variable-based approach presumes a direct-indirect relationship between import prices and inflation rate. The direct relationship is defined by the coefficient of import prices while the indirect relationship is measured by the addition of the coefficient of import prices and the dummybased coefficient of fall in import prices. In this study, we adapt the dummy variablebased model by Rassekh and Ranjbar (2014) to the autoregressive distributed lag (ARDL) modelling framework. There are two reasons for this. The first is to determine short-run validity for imported inflation and ratchet effect. Second, the ARDL facilitates an easy comparison between the results from the dummy variable-based asymmetric approach and the Nonlinear ARDL approach, as both would consist of short-run and longrun coefficients. Thus, the long-run model for analysing import prices - inflation rate dynamics in this study is specified as follows.

$$
L C P I_{t}=\alpha+\beta_{1} Y G_{t}+\beta_{2} L O P_{t}+\beta_{3} L I M P_{t}+\beta_{4}\left(D * L I M P_{t}\right)+\varepsilon_{t}
$$

where $L C P I_{t}$ is the $\log$ of the domestic consumer price index $(\mathrm{CPI})$ of the respective country, $Y G$ represents output gap computed as the deviation between actual and potential 


\section{Articles}

output using the Hodrick-Filter approach (see also, Salisu and Isah, 2018; Jašová et al., 2019), $L O P_{t}$ is the log of WTI oil price (see Salisu et al., 2018), $L I M P_{t}$ is the log of import price index, and $D$ is the dummy for negative import prices; $D=1$ if changes are negative and zero, otherwise.

In the original framework of Pesaran et al. (2001), the ARDL empirical specification for equation (1) can be presented as below:

$$
\begin{gathered}
\Delta L C P I_{t}=\alpha_{0}+\rho L C P I_{t-1}+\beta_{1} Y G_{t-1}+\beta_{2} L O P_{t-1}+\beta_{3} L I M P_{t}+\beta_{4} D I M P_{t} \\
\sum_{i=1}^{N 1} \lambda_{1 i} \Delta L C P I_{t-i}+\sum_{j=0}^{N 2} \lambda_{2 j} Y G_{t-j}+\sum_{j=0}^{N 3} \lambda_{3 j} \Delta L O P_{t-j}+ \\
\sum_{j=0}^{N 4} \lambda_{4 j} \Delta L I M P_{t-j}+\sum_{j=0}^{N 5} \lambda_{5 j} D I M P_{t-j}+\varepsilon_{t}
\end{gathered}
$$

Equation (2) is the representative ARDL model, which comprises both long-run and short-run estimates. Notably, $D I M P_{t}$ represents the multiplicative term of the dummy for negative import price changes and the import price, that is, $\left(D^{*} L I M P_{t}\right)$ in equation 1. The long-run parameters for the intercept and slope parameters are computed as; $-\frac{\alpha_{0}}{\rho}$ for the intercept, $-\frac{\beta_{1}}{\rho}$ for the coefficient of the output gap, $-\frac{\beta_{2}}{\rho}$ for the coefficient of oil price, $-\frac{\beta_{3}}{\rho}$ for the coefficient of import prices, and $-\frac{\beta_{4}}{\rho}$ for the coefficient of indirect negative import price. This is evident, since $\Delta I n C P I_{t}=\Delta Y G_{t}=\Delta I n O P_{t}=\Delta I n I M P_{t}=\Delta I n D I M P_{t}=0$ in the long run. However, the short-run estimates are obtained as $\lambda_{2 j}$ for the output gap, $\lambda_{3 j}$ for oil price, $\lambda_{4 j}$ for import prices, and $\lambda_{5 j}$ for the indirect effect of negative import prices.
Meanwhile, as the variables in first differences (short-run variables) can accommodate more than one lag, the optimal lag length for the ARDL model is using Akaike Information Criterion (AIC). The preferred ARDL model is used to test for the longrun relationship in the model. This approach of testing for co-integration is referred to as Bounds testing as it involves the upper and lower bounds. The test follows an $F$ distribution and therefore if the calculated F-statistic is greater than the upper bound, there is co-integration; if it is less than the lower bound, there is no co-integration and if it lies in-between the two bounds, then, the test is considered inconclusive (see also Oyinlola and Oloko, 2018).

To determine the speed of adjustment in a co-integrating ARDL model, equation (2) can be re-specified to include an error correction term as follows: 


$$
\begin{gathered}
\Delta L C P I_{t}=\delta v_{t-1}+\sum_{i=1}^{N 1} \lambda_{1 i} \Delta L C P I_{t-i}+\sum_{j=0}^{N 2} \lambda_{2 j} Y G_{t-j}+\sum_{j=0}^{N 3} \lambda_{3 j} \Delta L O P_{t-j}+ \\
\sum_{j=0}^{N 4} \lambda_{4 j} \Delta L I M P_{t-j}+\sum_{j=0}^{N 5} \lambda_{5 j} D I M P_{t-j}+\varepsilon_{t}
\end{gathered}
$$

where $v_{t-1}$ is the lagged error correction term calculated as $v_{t-1}=L C P I_{t-1}-\alpha_{0}^{*}-\beta_{1}^{*} Y G_{t-1}-\beta_{2}^{*} L O P_{t-1}-$ $\beta_{3}{ }^{*} L I M P_{t-1}-\beta_{4}{ }^{*} D I M P_{t-1}$, where $\alpha_{0}^{*}, \beta_{1}{ }^{*}, \beta_{2}{ }^{*}$ , $\beta_{3}{ }^{*}$, and $\beta_{4}{ }^{*}$ equal $-\frac{\beta_{1}}{\rho}$ for the coefficient of the output gap, $-\frac{\beta_{2}}{\rho}$ for the coefficient of oil price, $-\frac{\beta_{3}}{\rho}$ for the coefficient of import prices, and $-\frac{\beta_{4}}{\rho}$ for the coefficient of indirect negative import price, respectively. While the long-run positive effect of import prices on the inflation rate is measured by $\beta_{3}{ }^{*}$ the ratchet effect is measured by the sum of $\beta_{3}{ }^{*}$ and $\beta_{4}{ }^{*}\left(\beta_{3}^{*}+\beta_{4}^{*}\right)$. The ratchet effect exists if $\beta_{4}{ }^{*}$ is negative and statistically significant; implying that reduction in import prices does not reduce domestic prices as much as an equivalent increase in import prices would increase domestic prices This portrays downward rigidity in domestic prices.

\subsection{Nonlinear Autoregressive Distributed Lag (NARDL) model}

In modelling ratchet effect in import priceinflation nexus using NARDL, equation (1) would be specified with the dummy variable measure of asymmetry as follows:

$$
L C P I_{t}=\alpha+\beta_{1} Y G_{t}+\beta_{2} L O P_{t}+\beta_{3} L I M P_{t}+\varepsilon_{t}
$$

where the variables remained as earlier defined. Meanwhile, the asymmetric effect of import prices in this model is determined by decomposing import prices into positive and negative changes in import prices following Shin et al. (2014). Accordingly, positive changes in import prices $\left(L I M P_{t}^{+}\right)$and negative import prices $\left(L I M P_{t}^{-}\right)$are defined as follows:

$$
\begin{aligned}
& \operatorname{LIMP}_{t}^{+}=\sum_{j=1}^{t} \Delta L I M P_{j}^{+}=\sum_{j=1}^{t} \max \left(\Delta L I M P_{j}, 0\right) \\
& \operatorname{LIMP}_{t}^{-}=\sum_{j=1}^{t} \Delta L I M P_{j}^{-}=\sum_{j=1}^{t} \min \left(\Delta L I M P_{j}, 0\right)
\end{aligned}
$$

Hence, the standard NARDL specification can be expressed as:

$$
\begin{aligned}
\Delta L C P I_{t} & =\alpha_{0}+\rho L C P I_{t-1}+\beta_{1} Y G_{t-1}+\beta_{2} L O P_{t-1}+\beta_{3}^{+} L I M P_{t}^{+}+\beta_{3}^{-} L I M P_{t}^{-}+ \\
& \sum_{i=1}^{N 1} \lambda_{1 i} \Delta L C P I_{t-i}+\sum_{j=0}^{N 2} \lambda_{2 j} Y G_{t-j}+\sum_{j=0}^{N 3} \lambda_{3 j} \Delta L O P_{t-j}+ \\
& +\sum_{j=0}^{N 4}\left(\lambda_{4 j}^{+} \Delta L I M P_{t-j}^{+}+\lambda_{4 j}^{-} \Delta L I M P_{t-j}^{-}\right)+\varepsilon_{t}
\end{aligned}
$$




\section{Articles}

And, the short-run error correction model will be expressed as:

$$
\begin{aligned}
\Delta L C P I_{t} & =\tau \xi_{t-1}+\sum_{i=1}^{N 1} \lambda_{1 i} \Delta L C P I_{t-i}+\sum_{j=0}^{N 2} \lambda_{2 j} Y G_{t-j}+\sum_{j=0}^{N 3} \lambda_{3 j} \Delta L O P_{t-j}+ \\
& +\sum_{j=0}^{N 4}\left(\lambda_{4 j}^{+} \Delta L I M P_{t-j}^{+}+\lambda_{4 j}^{-} \Delta L I M P_{t-j}^{-}\right)+v_{t}
\end{aligned}
$$

where the error correction term, $\xi_{t-1}=L C P I_{t-1}-\alpha_{0}^{*}-\beta_{1}^{*} Y G_{t-1}-\beta_{2}{ }^{*} L O P_{t-1}-$ $\beta_{3}^{+^{*}} \operatorname{LIMP}_{t-1}^{+}-\beta_{3}^{-*} \operatorname{LIMP}_{t-1}^{-}$and $\alpha_{0}^{*}, \beta_{1}^{*}, \beta_{2}^{*}$, $\beta_{3}^{+^{*}}$, and $\beta_{3}^{-*}$ equal $-\frac{\beta_{1}}{\rho}$ for the coefficient of the output gap, $-\frac{\beta_{2}}{\rho}$ for the coefficient of oil price, $-\frac{\beta_{3}^{+}}{\rho}$ for the coefficient of positive changes in import prices, and $-\frac{\beta_{3}^{-}}{\rho}$ for the coefficient of negative changes in import price, respectively. Given this definition, therefore, the long-run model can be specified as:

$$
\begin{aligned}
L C P I_{t} & =\alpha_{0}^{*}+\beta_{1}^{*} Y G_{t}+\beta_{2}^{*} L O P_{t}+ \\
& +\beta_{3}^{+^{*}} L I M P_{t}^{+}+\beta_{3}^{-*} L I M P_{t}^{-}+\xi_{t}
\end{aligned}
$$

In the long run, the asymmetric effect is examined by comparing the positive and negative coefficients of import prices, $\beta_{3}^{+*}$ and $\beta_{3}^{-*}$. While $\beta_{3}^{+^{*}}$ explains the effect of increases in import prices on the inflation rate, $\beta_{3}^{-*}$ explains the effect of decreases in import prices on the inflation rate. The ratchet effect will hold in this case, if $\beta_{3}^{-*}$ is significantly less than $\beta_{3}^{+*}$. On the other hand, the short-run ratchet effect holds if the $\lambda_{4 j}^{-}$is significantly less than $\lambda_{4 j}^{+}$(see equation 8).

\section{Result presentation and empirical analysis}

\subsection{Analysis with Dummy Variable- based asymmetric ARDL models}

The results from Dummy Variable-based asymmetric model are presented in Table 3. From the table, the error correction term (ECM) coefficient shows no evidence of a long-run relationship between import prices and inflation rate in three (3) of the twelve (12) high-income countries. Likewise, the ECM shows no evidence of a long-run relationship between import prices and inflation rate in Brazil, while a long-run relationship exists for Paraguay, which is the second middle-income country. The results show that the coefficient of import prices (IMP) is always positive wherever it is significant in the short run and long run. This indicates that high import prices cause high inflation in almost all the countries either in the short run or long run. 


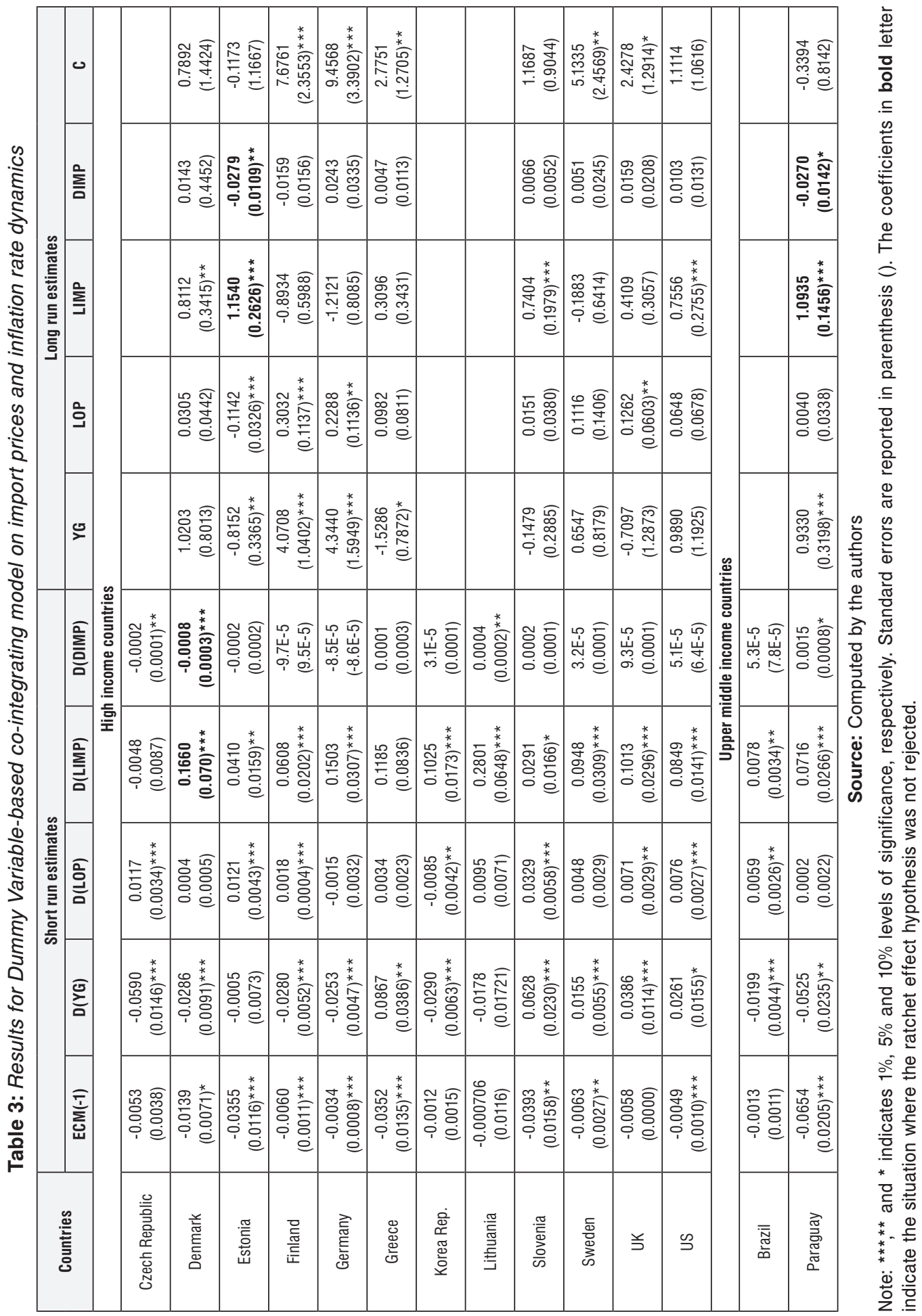




\section{Articles}

For high-income countries, the imported inflation hypothesis cannot be rejected for Denmark, Estonia, Slovenia, and the US in the short run and long run. The hypothesis cannot be rejected only in the short run for Finland, Germany, the Republic of Korea, Lithuania, Sweden, and the UK. The few high-income countries with no significant short-run or longrun imported inflation are the Czech Republic and Greece. This may suggest that the high inflation rates in these two countries is due to other factors apart from import prices. For example, oil price significantly influences the inflation rate of the Czech Republic, while the output gap or unemployment appears to account for the high inflation rate in Greece. For middle-income countries, however, the imported inflation hypothesis cannot be rejected for Paraguay both in the short run and long run, while it was not rejected for Brazil in the short run but not in the long run.

To examine the existence of the ratchet effect in the Dummy Variable-based asymmetric model, the coefficient of DIMP is expected to be negative and significant; which would ensure that the sum of the coefficients of IMP and DIMP is lower than the coefficient of IMP. The ratchet effect hypothesis was not rejected only for three (3) countries which consist of two (2) high-income countries and one (1) low (upper middle) income country. Specifically, the ratchet effect hypothesis holds for Denmark in the short run and for
Estonia and Paraguay in the long run. This indicates that low import prices reduce the inflation rate less proportionately than as high import prices increase the inflation rate. This happens to be the relationship between import prices and inflation rate in the short run in Denmark, and in the long run in Estonia and Paraguay. As ratchet effect (does not) exists in the import price - inflation rate nexus for high income and middle-income countries, it suggests that the problem of ratchet effect is country-specific, and can happen in high income as well as middle-income countries. This validates the results by Rassekh and Wilbratte (1990), Shirvani and Wilbratte (1999), and Rassekh and Ranjbar (2014) for developed economies on one hand, the results by Alsamara et al. (2018; 2020) for emerging economies on the other.

With the significance of ratchet effect in these countries, it implies that maintaining a (symmetric) rule-based counter-cyclical monetary policy against import price shocks would be inefficient, and monetary policy could have an adverse economic effect in the medium to long term (Bernanke et al., 1997; Kormilitsina, 2011; Oloko et al., 2021). Therefore, Denmark, Estonia, and Paraguay would need to adopt a discretionary monetary policy or design an asymmetric rule-based counter-cyclical monetary policy against import price shocks. 


\section{Articles}

\subsection{Analysis with NARDL model}

In Table 4, the results for the NARDL model on import prices-inflation rate relationship are presented. The NARDL model confirms longrun relationship in more countries than the Dummy Variable-based asymmetric model. As evident, the ECM coefficients show that there is long-run relationship between import prices and the inflation rate in all countries except the Czech Republic. The positive and significant effect of positive import prices on the inflation rate confirms the existence of imported inflation, which indicates that higher import prices caused higher inflation in high-income and middle-income countries. Thus, the results show that imported inflation exists in the short run and long run in six (6) countries (Estonia, Lithuania, Sweden, the US, Brazil, and Paraguay), only in the short run in three (3) countries (the Czech Republic, Denmark, and Slovenia), only in the long run in four (4) countries (Finland, Germany, the Republic of Korea, and the UK). The result for Greece not being subjected to imported inflation was further confirmed in the NARDL
Ratchet Effect in Import Prices - Inflation Rate Nexus

model as in the Dummy Variable-based asymmetric model.

To confirm the existence of ratchet effect in the NARDL model, the coefficient of IMP_NEG is expected to be lower than that of LIMP_POS; which would indicate that lower import prices reduce inflation rate less proportionately than as high import prices will increase the inflation rate. This may be validated when the coefficient of LIMP_NEG is significantly lower than that of the LIMP_ POS or statistically insignificant (see Rassekh and Ranjbar, 2014). This condition indicates the existence of downward rigidity in domestic prices, and eventually, a ratchet effect. As evident from the results (in Table 4), the ratchet effect was confirmed for more countries using the NARDL model compared to when the Dummy Variable-based asymmetric model was employed. This suggests that accounting for asymmetry in import prices using the recently developed approach by Shin et al. (2014) is better than accounting for the asymmetry using the dummy variable-based approach adopted in the earlier studies. 


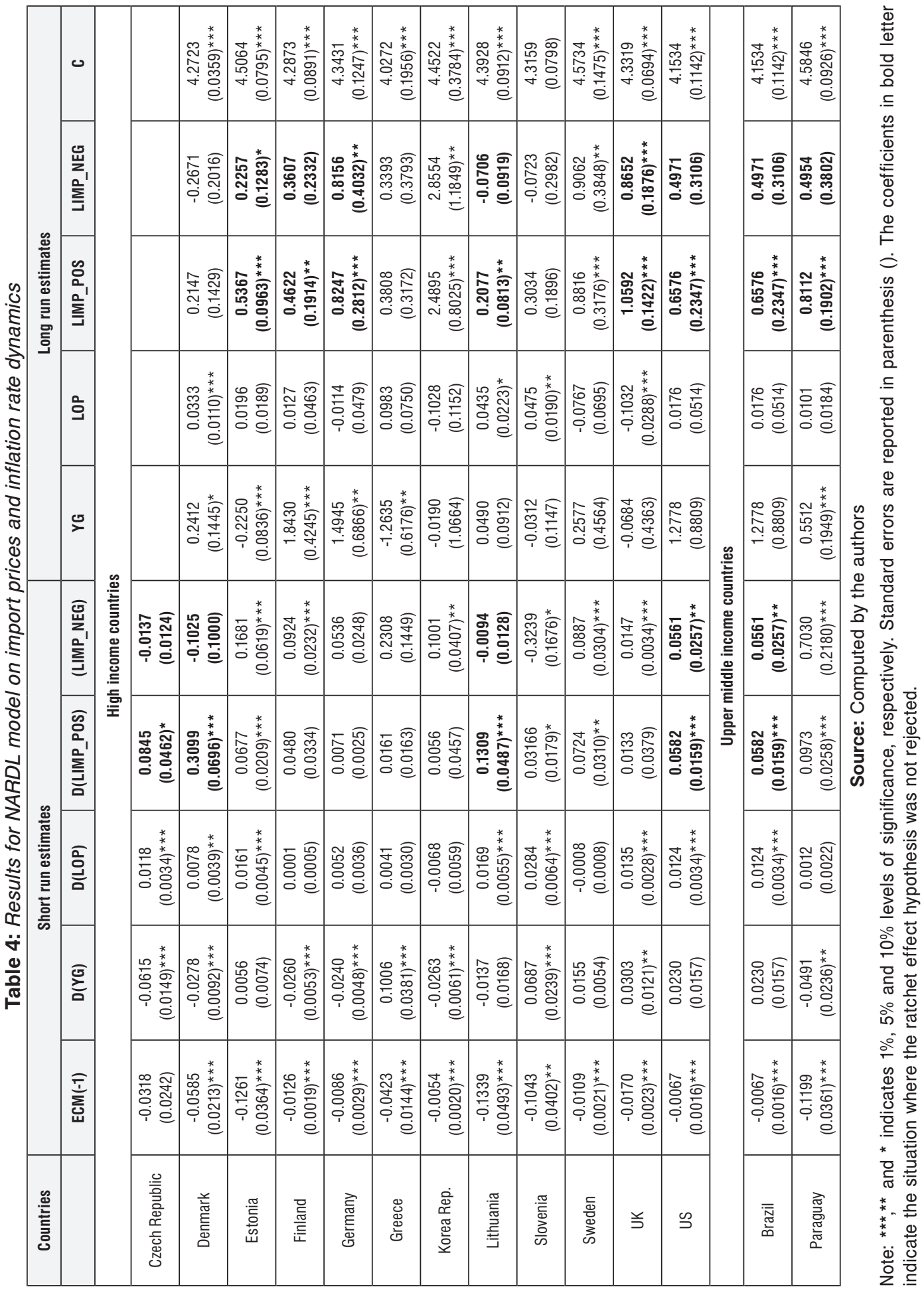




\section{Articles}

Specifically, the ratchet effect hypothesis was confirmed both in the short run and long run for Estonia, Lithuania, and the US, which are developed (high income) countries, and for Brazil, which is an emerging (upper middle income) country. Similarly, the ratchet effect was confirmed only in the long-run for highincome countries such as Finland, Germany, and the UK, and for a middle-income country, Paraguay. The ratchet effect was confirmed only in the short run for the Czech Republic and Denmark; whereas, no evidence of the ratchet effect in Greece, the Republic of Korea, Slovenia, and Sweden. For these countries, the results suggest that inflation in the Republic of Korea, Sweden, and Greece is largely driven by productivity, as indicated by a statistically significant coefficient of the output gap. More so, the increase in economic productivity and increase in oil prices significantly influenced changes in the domestic inflation rate of Slovenia.

The results suggest that the problem of the ratchet effect is country-specific, and can happen in high-income as well as middleincome countries. This partly validates the results by Rassekh and Wilbratte (1990), Shirvani and Wilbratte (1999), and Rassekh and Ranjbar (2014) for developed economies, the results by Alsamara et al. $(2018 ; 2020)$ for emerging economies. With the significance of the ratchet effect in these countries, it implies that maintaining a (symmetric) rulebased counter-cyclical monetary policy when dealing with import price shocks would be inefficient, and can make monetary policy have an adverse effect on the economy in the medium to long term (Bernanke et al., 1997; Kormilitsina, 2011; Oloko et al., 2021). Therefore, high-income countries such as Denmark, the Czech Republic, Estonia, Finland, Germany, Lithuania, and the UK, and
Ratchet Effect in Import Prices - Inflation Rate Nexus

middle-income countries such as Brazil and Paraguay would need to adopt a discretionary monetary policy or design an asymmetric rule-based counter-cyclical monetary policy against import price shocks.

\section{Conclusion}

This study investigated the existence of ratchet effect in the import prices-inflation rate nexus for high-income and middleincome countries. It employed both the indirect asymmetric approach with dummy variable-based co-integration and the direct asymmetric approach with Nonlinear Autoregressive Distributed Lag (NARDL) models. From our empirical analysis, the ratchet effect was confirmed for more countries using the NARDL model compared with the dummy variable-based asymmetric approach. Specifically, while the dummy variable-based asymmetric approach shows that the ratchet effect hypothesis holds only in the cases of three (3) countries; consisting of two (2) high-income countries and one (1) upper middle-income country, the NARDL model confirms the ratchet effect hypothesis in ten (10) countries; consisting of eight (8) high-income countries and two (2) middle income countries. Furthermore, the results show that imported inflation exists in the short run and long run in six (6) countries (Estonia, Lithuania, Sweden, the US, Brazil, and Paraguay). It exists only in the short run in three (3) countries (the Czech Republic, Denmark, and Slovenia) and only in the long run in four (4) countries (Finland, Germany, the Republic of Korea, and the UK). The fact that imported inflation and ratchet effect exist in high-income and middle-income countries suggests that the issue of imported inflation and ratchet effect is country-specific. 


\section{Articles}

Overall, with the significance of the ratchet effect in these countries, it implies that maintaining a (symmetric) rule-based countercyclical monetary policy when dealing with import price shocks would be inefficient, and can make monetary policy have an adverse effect on the economy in the medium to long term (Bernanke et al., 1997; Kormilitsina, 2011; Oloko et al., 2021). Therefore, each country should examine the existence or otherwise of ratchet in its import price-inflation rate nexus to determine whether it should adopt a symmetric or an asymmetric rule-based counter-cyclical monetary policy against import price shocks.

\section{References}

Abbas, S. K. and Lan, H. "Commodity price pass-through and inflation regimes," Energy Economics, 92, 2020, 104977.

Alhassan, A. L. and Fiador, V. "Insurancegrowth nexus in Ghana: An autoregressive distributed lag bounds cointegration approach," Review of Development Finance 4(2), 2014, 83-96.

Alsamara, M., Mrabet, Z. and Dombrecht, M. "Asymmetric import cost pass-through in GCC countries: Evidence from nonlinear panel analysis," Economic Modelling 75, 2018, 432440.

Alsamara, M., Mrabet, Z. and Hatemi-J., A. "Pass-through of import cost into consumer prices and inflation in GCC countries: Evidence from a nonlinear autoregressive distributed lags model," International Review of Economics and Finance 70, 2020, 89-101.

Bernanke, B.S., Gertler, M., Watson, M., Sims, C.A., Friedman, B.M., 1997. Systematic monetary policy and the effects of oil price shocks. Brook. Pap. Econ. Activity 1997 (1), 91-157.

Blackburne, E. F. and Frank, M. W., "Estimation of nonstationary heterogeneous panels," The Stata Journal 7(2), 2007, 197-208.
Cardella, E. and Depew, B. (2018). Output restriction and the ratchet effect: Evidence from a real-effort work task. Games and Economic Behavior, 107, 182-202.

Charness, G., Kuhn, P. and Villeval, M. C. (2011). Competition and the ratchet effect. Journal of Labor Economics, 29(3), 513-547.

Corrigan, T. D., "The Relationship Between Import Prices and Inflation in the United States." WCOB Faculty Publications Paper 18, 2005.

Goldstein, M., "Downward Price Inflexibility, Ratchet Effects, and the Inflationary Impact of Import Price Changes: Some Empirical Evidence." Staff Papers (International Monetary Fund) 24(3), 1977, 569-612.

Hottman, C. J., and Monarch, R. (2020). A matter of taste: Estimating import price inflation across US income groups. Journal of International Economics, 127, 103382.

Jašová, M., Moessner, R. and Takáts, E. (2019). Domestic and global output gaps as inflation drivers: What does the phillips curve tell?" Economic Modelling, in press. 10.1016/j. econmod.2019.07.025

Kormilitsina, A., 2011. Oil price shocks and the optimality of monetary policy. Rev. Econ. Dyn. 14 (1), 199-223.

Lagoa, S. (2014). Inflation dynamics in open economies: empirical evidence for G7 countries on

the role of import prices and the cost channel. Research in Economics 68(4), 354- 371.

McCarthy, J., "Pass-through of Exchange Rates and Import Prices to Domestic Inflation in Some Industrialized Economies," Eastern Economic Journal 33, 2007, 511-537.

Murthy, V. N. R., and Okunade, A. A., "Determinants of U.S. health expenditure: Evidence from autoregressive distributed lag (ARDL) approach to cointegration," Economic Modelling 59, 2016, 67-73. 
Oloko, T. F., Ogbonna, A. E., Adedeji, A. A., \& Lakhani, N. "Oil price shocks and inflation rate persistence: A Fractional Cointegration VAR approach," Economic Analysis and Policy, 70, 2021, 259-275.

Osorio, C. and Unsal, D. F., "Inflation dynamics in Asia: Causes, changes, and spillovers from China," Journal of Asian Economics 24, 2013, 26-40.

Oyinlola, M. A. and Oloko, T. F., "Exchange rate dynamics and stock market performance in Nigeria: Evidence from a Nonlinear ARDL approach," West African Financial and Economic Review 18(1), 2018, 27-46.

Pesaran, M. H., and Smith, R. P., "Estimating long-run relationships from dynamic heterogeneous panels," Journal of Econometrics 68, 1995, 79-113.

Pesaran, M. and Shin, Y. "An Autoregressive Distributed Lag Modeling Approach to

Cointegration Analysis," in S. Strom, eds., Econometrics and Economic Theory in the 20th Century: The Ragnar Frisch Centennial Symposium, Cambridge University Press: Cambridge.

Pesaran, M. H., Shin, Y. and Smith, R. P., "Estimating long-run relationships in dynamic heterogeneous panels," DAE Working Papers Amalgamated Series 9721, 1997.

Pesaran, M. H., Shin, Y. and Smith, R. P. "Pooled mean group estimation of dynamic heterogeneous panels," Journal of the American Statistical Association 94, 1999, 621-634.

Pesaran, M.H., Shin, Y. and Smith, R.J. "Bounds testing approaches to the analysis of level relationship," Journal of Applied Economics 16, 2001, 289-326.

Rassekh, F. and Ranjbar, O., "An Empirical Investigation of the Ratchet Effect in the OECD, 1985-2009," International Economic Journal 28(1), 2014, 183-190.
Rassekh, F. and Wilbratte, B., "The Effect of Import Price Changes on Domestic Inflation: An Empirical Test of the Ratchet Effect: Note," Journal of Money, Credit and Banking 22, 1990, 263-267.

Salisu, A. A. and Isah, K. O., "Revisiting the oil price and stock market nexus: A nonlinear Panel ARDL approach," Economic Modelling 66, 2017, 258-271.

Salisu, A. A., and Isah, K. O., "Predicting US inflation: Evidence from a new approach," Economic Modelling 71, 2018, 134-158.

Salisu, A. A., Adediran, I. A., Oloko, T. O. and Ohemeng, W., "The heterogeneous behaviour of the inflation hedging property of cocoa," The North American Journal of Economics and Finance, 2019, 101093. doi:10.1016/j. najef.2019.101093

Salisu, A. A., Ademuyiwa, I., and Isah, K. O., "Revisiting the forecasting accuracy of Phillips curve: The role of oil price," Energy Economics 70, 2018, 334-356.

Shin, Y., Yu, B. and Greenwood-Nimmo, M., "Modelling asymmetric cointegration and dynamic multipliers in an ARDL framework," In: Horrace, W.C., 2014.

Shirvani, H. and Wilbratte, B., "The Asymmetric Response of Domestic Prices to Changes in Import Prices: A Cointegration Test of the Rachet Effect," Journal of Macroeconomics 21, 1999, 381-396.

Tootell, G., "Globalization and U.S. inflation," New England Economic Review, 1998, 21-33.

Tule, M. K., Salisu, A. A., and Ebuh, G. U. (2019). A test for inflation persistence in Nigeria using fractional integration \& fractional cointegration techniques. Economic Modelling, doi:10.1016/j.econmod.2019.07.024.

Wei, C. (2020). Can job rotation eliminate the Ratchet effect: Experimental evidence. Journal of Economic Behavior \& Organization, 180, 66-84. 